\title{
DAMPAK PELANGGARAN ASN ATAS SE MENTERI PANRB NO. B/2355/M.PANRB/07/2015 DALAM LAYANAN BIROKRASI
}

\author{
Syaefullah \\ Institut Pemerintahan Dalam Negeri NTB \\ Jl. Gajah Mada No.1, Leneng, Praya, Kabupaten Lombok Tengah \\ Indonesia \\ Email : syaefullah19@gmail.com
}

\begin{abstract}
Abstrak
Tujuan dari penelitian ini adalah untuk mengkaji dampak pelanggaran ASN terhadap SE Menteri PANRB yang berdampak pada pelanggaran ketentuan Pasal 33 ayat (3) UndangUndang Nomor 5 Tahun 2014 tentang Aparatur Sipil Negara, masalah yang ingin dikaji adalah bagaimana dampak dan penerapan pelanggaran ASN menurut Undang-Undang Nomor 5 Tahun 2014 tentang Aparatur Sipil Negara sesuai ketentuan pasal 33 ayat (3), adapun metode penelitian yang digunakan dalam tulisan ini adalah penelitian normatif dengan metode pendekatan peraturan perundang-undangan (statute approach); pendekatan konseptual (conceptual approach); dan pendekatan Kasus (case approach, Analisis, dalam pendekatan konseptual adalah pemberian sanksi administratif sesuai dengan UU ASN mulai dari sanksi sedang dan sanksi berat, sedangkan pendekatan kasus adalah sanksi pelanggaran berat yang dilakukan ASN dalam Pilkada 2018 dengan hukuman pidana oleh Gakkumdu.
\end{abstract}

\section{Kata kunci: Netralitas; Pilkada; UU Aparatur Sipil Negara.}

\section{A. PENDAHULUAN}

Tujuan Pembangunan Nasional adalah untuk menciptakan masyarakat yang adil dan makmur yang sama dan terus menerus baik material dan spiritual. Hal ini dapat dicapai, salah satunya adalah dengan hadirnya Aparatur Sipil Negara sebagai Warga Negara, sebagai Unsur Aparatur Negara, Aparatur Sipil Negara, dan PPPK yang penuh loyalitas dan kepatuhan kepada Pancasila, UUD 1945, Negara dan Pemerintah. Sebagaimana pendapat E.Utrecht yang dikutip oleh Muchsan dalam bukunya Hukum Kepegawaian, bahwa negara merupakan badan hukum yang terdiri dari persekutuan orang (Gemeenschaap Van Merten) yang ada karena perkembangan faktor-faktor sosial dan politik dalam sejarah. ${ }^{1}$ Berdasarkan pendapat tersebut dapat diketahui bahwa negara sebagai organisasi kekuasaan merupakan suatu badan yang berstatus hukum sebagai

${ }^{1}$ Muchsan, Hukum Kepegawaian, Bina Aksara, Jakarta, 1982, hlm. 10 . pendukung hak dan kewajiban (subyek hukum). ${ }^{2}$ Negara akan mencapai tujuannya dengan menggunakan status badan hukum beserta hak dan kewajibannya tersebut. ${ }^{3}$ Hak dan kewajiban yang dilaksanakan oleh aparatur negara didistribusikan kepada jabatan-jabatan negara. Aparatur Sipil Negara yang melaksanakan hak dan kewajiban negara yang disebut subyek hukum adalah Pegawai Negeri yang sekarang menjadi ASN. Hubungan antara ASN dengan negara menimbulkan kaidah-kaidah dalam hukum kepegawaian.

Kelancaran dalam implementasi pembangunan dan pemerintahan tergantung pada kesempurnaan dan kemampuan aparatur negara, dalam hal ini ASN. Posisi dan peran Aparatur Sipil Negara dalam setiap organisasi pemerintah sangat penting, karena ASN adalah tulang punggung pemerintah dalam melaksanakan pembangunan nasional. Aparatur Sipil Negara sebagai abdi Negara

\footnotetext{
${ }^{2}$ Ibid.

${ }^{3}$ Ibid.
} 
dan abdi masyarakat yang dengan penuh kesetian dan ketaatan kepada Pancasila, Undang-Undang Dasar 1945, Negara dan Pemerintah dalam menyelenggarakan tugas pemerintahan dan pembangunan serta wajib menjaga persatuan dan kesatuan bangsa dalam Negara Kesatuan Republik Indonesia.

Tugaskenegaraandanjabatanyangdiemban ASN agar dapat berjalan dengan lancar, dan dapat menunjang kelancaran pembangunan Nasional, maka setiap ASN tersebut harus memiliki kemampuan dan kualitas tinggi serta dengan tingkat disiplin yang tinggi dan berintegritas sesuai sumpah dan janjinya pada saat diangkat sebagai Pegawai Negeri. Aparatur Sipil Negara sebagai aparatur negara yang memberikan pelayanan kepada masyarakat secara profesional, jujur, adil dan merata dalam penyelenggarakan tugas negara, pemerintahan dan pembangunan harus bersikap netral dan tidak berpihak atau mementingkan dirinya, kelompok suku atau golongannya. ASN harus bersikap netral dari pengaruh semua golongan dan partai politik dan tidak diskriminatif dalam memberikan pelayanan kepada masyarakat sehingga layanan birokrasi tetap berjalan sesuai koridor yang telah digariskan oleh negara.

Untuk menjaga hal tersebut pemerintah telah mengeluarkan peraturan yang berfungsi untuk menjaga, mengawasi dan menjadi alat kontrol ASN melalui UU nomor 5 Tahun 2014 tentang Aparatur Sipil Negara. Selain itu juga pemerintah melalui Kementerian PAN RB telah membuat surat edaran dalam menjaga disipilin dan sikap netralitas dari ASN sehingga tidak terjebak dalam rajutan politik.

Namun demikian fenomena ASN yang sering terlibat politik praktis dan bersikap tidak netral ini ini telah berlangsung sampai dengan sekarang ini di mana masih banyak ditemukan laporan baik itu laporan masyarakat, lembaga swadaya masyarakat maupun temuan langsung dari badan pengawas pemilihan umum di setiap Kabupaten/Kota menemukan fenomena ini. Oleh karena banyaknya keterlibatan dari Aparatur Sipil Negara ini menimbulkan keprihatinan dan perhatian dari lembaga pembina dan pengawas ASN dalam hal ini KASN. Dalam menindaklanjuti terhadap temuan pelanggaran yang banyak melibatkan ASN tersebut, maka implementasi Peraturan kedisiplinan yang ditujukan bagi ASN, agar dapat ditaati dengan baik, maka hukuman terhadap pelanggaran yang terjadi harus diterapkan secara jelas dan tegas. Berdasarkan latar belakang permasalahan tersebut, penulis ingin melakukan penelitian yang menitikberatkan pada penegakan kedisiplinan yang ada pada diri ASN sesuai dengan peraturan yang diatur dalam UndangUndang No 5 tahun 2014 tentang ASN serta di kaitkan dengan Undang-Undang No. 10 tahun 2016 dengan judul "DAMPAK PELANGGARAN ASN ATAS SE Menteri PANRB NO. B/2355/M.PANRB/07/2015 DALAM LAYANAN BIROKRASI". Berdasarkan latar belakang permasalahan tersebut, dapat dirumuskan masalah sebagai berikut: "Bagaimana Dampak pelanggaran ASN terhadap SE Menteri PANRB N0. B/2355/M.PANRB/07/2015

DALAM LAYANAN BIROKRASI"

\section{B. METODE PENELITIAN}

Metode penelitian yang digunakan dalam tulisan ini adalah penelitian normatif dengan metode pendekatan peraturan perundangundangan (statute approach); pendekatan konseptual (conseptual approach); dan pendekatan Kasus (case approach) ${ }^{4}$

\section{PEMBAHASAN}

\section{Analisis Dampak Pelanggaran Aparatur Sipil Negara dari Pendekatan Konsep- tual (Conseptual Approach)}

\footnotetext{
${ }^{4}$ Satya Adi Permana, Lalu Sabardi, Djumardin, "Tanggung Jawab Notaris Atas Akta Salinan Yang Dibuat Tanpa Minuta Akta", Jurnal Hukum Jatiswara, [S.1.], v. 32, n. 2, nov. 2017. ISSN 2579-3071. Available at: $<$ http://jatiswara. unram.ac.id/index.php/js/article/view/122>. Date accessed: 17 feb. 2019.
} 
Pengertian dampak menurut Kamus Besar Bahasa Indonesia adalah benturan, pengaruh yang mendatangkan akibat baik positif maupun negatif. Pengaruh adalah daya yang ada dan timbul dari sesuatu (orang, benda) yang ikut membentuk watak, kepercayaan atau perbuatan seseorang. Pengaruh adalah suatu keadaan dimana ada hubungan timbal balik atau hubungan sebab akibat antara apa yang mempengaruhi dengan apa yang dipengaruhi ${ }^{5}$.

Dampak secara sederhana bisa diartikan sebagai pengaruh atau akibat. Dalam setiap keputusan yang diambil oleh seorang atasan biasanya mempunyai dampak tersendiri, baik itu dampak positif maupun dampak negatif. Dampak juga bisa merupakan proses lanjutan dari sebuah pelaksanaan pengawasan internal. Seorang pemimpin yang handal sudah selayaknya bisa memprediksi jenis dampak yang akan terjadi atas sebuah keputusan yang akan diambil.

Sebagaimana yang tercantum dalam Pasal 1 ayat 1 dan ayat 2 Undang-Undang Nomor 5 Tahun 2014 selanjutnya di singkat ASN, yaitu sebagai berikut: Aparatur Sipil Negara adalah profesi bagi pegawai negeri sipil dan pegawai pemerintah dengan perjanjian kerja yang bekerja pada instansi pemerintah. Aparatur Sipil Negara adalah pegawai negeri sipil dan pegawai pemerintah dengan perjanjian kerja yang diangkat oleh pejabat pembina kepegawaian dan diserahi tugas dalam suatu jabatan pemerintahan atau diserahi tugas negara lainnya dan digaji berdasarkan peraturan perundang-undangan. ${ }^{6}$

Asas netralitas berdasarkan UndangUndang Nomor 5 Tahun 2014 adalah bahwa setiap Pegawai ASN tidak berpihak dari segala bentuk pengaruh manapun dan tidak memihak kepada kepentingan siapapun. Netralitas dapat juga diartikan dengan bersikap tidak memihak terhadap sesuatu apapun ${ }^{7}$. Dalam konteks ini netralitas diartikan sebagai tidak terlibatnya pegawai negeri sipil dalam pemilihan Kepala Daerah baik secara aktif maupun pasif.

Menurut Rouke mengatakan netralitas birokrasi dari politik adalah hampir tidak mungkin, sebab jika partai politik tidak mampu memberikan alternatif program pengembangan dan mobilisasi dukungan, maka birokrasi akan melaksanakan tugastugas itu sendiri dan mencari dukungan politik di luar partai politik yang bisa membantunya dalam merumuskan kebijakan politik ${ }^{8}$.

Netralitas menurut Azhari dalam merupakan kondisi terlepasnya birokrasi spoil system yang berarti borokrasi bekerja berdasarkan profesionalisme dan kemampuan teknis yang dibutuhkan'. Menurut Thoha dalam netralitas birokrasi pada hakikatnya adalah suatu sistem dimana birokrasi tidak akan berubah dalam memberikan pelayanan kepada masternya (dari parpol yang memerintah), biarpun masternya berganti dengan master (parpol) lain ${ }^{10}$. Pemberian pelayanan tidak bergeser sedikit pun walau masternya berubah. Birokrasi dalam memberikan pelayanan berdasarkan profesionalisme bukan karena kepentingan politik.

Adapun kode etik dan kode perilaku yang dimaksud, yaitu:

(1) Kode etik dan kode perilaku sebagaimana dimaksud dalam Pasal 3 huruf $b$ bertujuan untuk menjaga martabat dan kehormatan ASN.

(2) Kode etik dan kode perilaku sebagaimana dimaksud pada ayat (1) berisi pengaturan perilaku agar Pegawai ASN:

a) melaksanakan tugasnya dengan jujur, bertanggung jawab, dan berintegritas tinggi;

b) melaksanakan tugasnya dengan cermat dan disiplin;

c) melayani dengan sikap hormat, sopan, dan tanpa tekanan;

\footnotetext{
${ }^{8}$ Watunglawar, 2015, hal. 26,

${ }^{9}$ Patria, 2015, hal. 21,

${ }^{10}$ Ibid.
}

${ }^{6}$ UU No. 5 Tahun 2014 tentang Aparatur Sipil Negara.

${ }^{7}$ Yamin, 2015, hal. 13 
d) melaksanakan tugasnya sesuai dengan ketentuan peraturan perundangundangan;

e) melaksanakan tugasnya sesuai dengan perintah atasan atau pejabat yang berwenang sejauh tidak bertentangan dengan ketentuan peraturan perundangundangan dan etika pemerintahan;

f) menjaga kerahasiaan yang menyangkut kebijakan negara;

g) menggunakankekayaandanbarangmilik negarasecarabertanggungjawab,efektif, dan efisien;

h) menjaga agar tidak terjadi konflik kepentingan dalam melaksanakan tugasnya;

i) memberikan informasi secara benar dan tidak menyesatkan kepada pihak lain yang memerlukan informasi terkait kepentingan kedinasan;

j) tidak menyalahgunakan informasi intern negara, tugas, status, kekuasaan, dan jabatannyauntuk mendapat atau mencari keuntunganataumanfaatbagidirisendiri atau untuk orang lain;

k) memegang teguh nilai dasar ASN dan selalu menjaga reputasi dan integritas ASN; dan

1) melaksanakan ketentuan peraturan perundangundangan mengenai disiplin Pegawai ASN. ${ }^{11}$

Di dalam Undang-Undang Nomor 5 Tahun 2015 Tentang Aparatur Sipil Negara menjelaskan yaitu Aparatur Sipil Negara yang selanjutnya disingkat ASN adalah profesi bagi pegawai negeri sipil dan pegawai pemerintah dengan perjanjian kerja yang bekerja pada instansi pemerintah. Pegawai Aparatur Sipil Negara yang selanjutnya disebut Pegawai ASN adalah pegawai negeri sipil dan pegawai pemerintah dengan perjanjian kerja yang diangkat oleh pejabat pembina kepegawaian dan diserahi tugas dalam suatu jabatan pemerintahan atau diserahi tugas negara lainnya dan digaji berdasarkan peraturan perundang-undangan. Pegawai Negeri Sipil

\footnotetext{
${ }^{11}$ UU No. 5 Tahun 2014 tentang Aparatur Sipil Negara.
}

yang selanjutnya disingkat PNS adalah warga negara Indonesia yang memenuhi syarat tertentu, diangkat sebagai Pegawai ASN secara tetap oleh pejabat pembina kepegawaian untuk menduduki jabatan pemerintahan.

Ketidaknetralan dari ASN ini tentu memberikan dampak ataupun akibat yang mungkin bisa menguntungkan salah satu pihak. Ketidaknetralan dari ASN khususnya di Kabupaten Bantul bisa memunculkan hal yaitu yang pertama, tugas ASN adalah memberikan pelayanan kepada masyarakat yang merupakan tugas utama dari birokrat. Akibat tidak adanya netralitas dari ASN maka dalam memberikan pelayanan bisa lebih cenderung bersifat sangat baik kepada calon yang didukungnya. Atau mengakibatkan tidak adanya keadilan dalam memberikan pelayanan. Tentu ini jelas melanggar asas keadilan dan kesetaraan dalam memberikan pelayanan atau dari tidak netralnya ASN ini menimbulkan tidak bekerja secara profesional saat calon yang didukungnya melakukan administratif di birokrasi. Kedua, dari 3 ketidaknetralan dari ASN yaitu adanya promisi jabatan atau kenaikan jabatan kepada mereka ASN yang mendukung kepala daerah pada saat pilkada. Yang dimana sebelum pilkada dilakukan, telah dijanjikan sesuatu. Atau adanya balasan timbal balik, dan hal ini bukan lah sesuatu yang baru lagi.

Untuk mencegah hal tersebut atau sebagai bentuk antisipasi agar ASN berikap dan menjadi integritasnya, maka Menteri Pedayagunaan Aparatur Negara dan Reformasi Birokrasi (PAN-RB) Yuddy Chrisnandi mengeluarkan Surat Edaran nomor B/2355/M.PANRB/07/2015 tanggal 22 Juli 2015 yang isinya menegaskan, bahwa seluruh Aparatur Sipil Negara (ASN) harus bersikap netral.

"Sesuai dengan UU No. 5/2014 tentang ASN, PNS yang menjadi anggota dan/ atau pengurus partai politik, akan dijatuhi hukuman berupa diberhentikan dengan tidak hormat," bunyi Surat Edaran yang ditujukan kepada Menteri Kabinet Kerja, Panglima TNI, 
Kapolri, Jaksa Agung, para Kepala Lembaga Pemerintah Non Kementerian (LPNK), para Sekjen Lembaga Negara, para Pimpinan Kesekretariatan Lembaga Non Struktural, para Gubernur, Bupati, dan Walikota itu. Surat Edaran itu juga mengingatkan, sesuai Peraturan Pemerintah Nomor 53 Tahun 2010, Selain PNS dilarang memberikan dukungan kepada calon Kepala Daerah/ Wakil Kepala Daerah.

Untuk menjamin efektivitas surat edaran tersebut, diminta kepada para pimpinan $\mathrm{K} / \mathrm{L}$ dan Pemda untuk melakukan pengawasan terhadap ASN yang berada di lingkungan instansi masing-masing. selain menjaga netralitas dalam pilkada, dalam Surat Edaran Menteri PAN-RB itu juga ditegaskan, bahwa aset pemerintah dilarang dipergunakan untuk kampanye.

Berdasarkan uraian di atas bahwa secara konseptual seorang ASN yang melakukan perbuatan tidak netral dalam pelaksanaan pemilukada, maka dia akan terkena sanksi mulai dari sanksi ringan, sedang dan berat. Yang membawa konsekuensi pada kondite atau prestasi kerjanya akan bernilai buruk, apalagi kalau sudah dijatuhkan oleh KASN, maka akan direkomendasikan kepada pejabat pembina kepegawaian daerah provinsi maupun kabupaten/kota bahwa ASN yang bersangkutan memiliki prestasi kerja yang dinilai buruk. Akibatnya adalah ketika akan ikut kompetisi pengembangan karier ASN tersebut akan terhambat, karena tidak akan pernah diluluskan oleh KASN baik dalam mengikuti Assesment ASN maupun seleksi jabatan Pimpinan Tinggi.

\section{Analisis Dampak Pelanggaran Aparatur Sipil Negara dari Sisi Pendekatan Kasus (Casse Approach)}

Terlibat Kampanye, Empat ASN Kota Bima Disidang ${ }^{12}$, berdasarkan laporan masyarakat tersebut kemudian ke empat Aparatur sipil negara (ASN) Pemerintah Kota Bima dipanggil oleh panwaslu kota bima dan

\footnotetext{
${ }^{12}$ Lombok Post .net, 26 Februari 2018
}

mereka memenuhi undangan klarifikasi yang dilayangkan Panwaslu Kota Bima, pada hari Sabtu tanggal 24 pebruari 2018. Dari lima orang yang dilaporkan, ternyata hanya empat orang yang ASN. Tiga diantaranya adalah Camat Raba SF, Lurah Ntobo SR dan staf Diskominfo Kota Bima RL. Sementara AN, statusnya bukan ASN. Yang berstatus ASN adalah suaminya.

Kejadian ini bermula ketika Tim Pemenangan Pasangan LUTFER, Anu Sirwan menandatangani laporan pada Kamis siang tanggal 22 pebruari 2018 bertempat di Kantor Panwaslu Kota Bima. Tapi sebelumnya ia telah melaporkan dugaan keterlibatan ASN tersebut pada Selasa sore tanggal 20 pebruari 2018. Sementara kejadian dugaan kampanye yang dilakukan Camat Raba SF pada Minggu tanggal 18 bulan pebruari tahun 2018 .

Mengaju pada Undang-Undang No. 10 Tahun 2016 tentang perubahan kedua atas UU Nomor 1 Tahun 2015 tentang penetapan peraturan pemerintah pengganti UU Nomor 1 Tahun 2014 tentang pemilihan Gubernur, Bupati, dan Walikota, maka Kasus dugaan Tindak Pidana Pemilihan Umum (Tipilu) dengan tersangka oknum Camat Raba, SF, Polisi sudah selaku anggota Gakkumdu telah dilakukan tahap dua, dimana Tersangka dan barang bukti kasus tersebut diserahkan ke penyidik Kejaksaan Negeri Bima.

Diketahui, berdasarkan hasil pantauan SF resmi ditetapkan sebagai tersangka dalam kasus dugaan tindak pidana pemilihan umum. SF ditetapkan sebagai tersangka setelah dilakukan gelar perkara, pada hari Jumat tanggal 2 Maret 2018. Dalam melakukan gelar perkara penetapan tersangka terhadap Camat Raba, Polisi sudah mengeluarkan surat panggilan pemeriksaan terhadap tersangka, rencananya pada hari Senin. Surat panggilan pemeriksaan sebagai tersangka tersebut, juga ditembuskan ke Wali Kota Bima. Setelah tersangka diperiksa, berkas kasus tersebut akan dirampungkan. Kemudian dilakukan gelar perkara dan berkas dilimpahkan ke kejaksaan. SF dinyatakan melanggar UndangUndang nomor 10 Tahun 2016 tentang 
perubahan kedua atas UU Nomor 1 Tahun 2015 tentang penetapan peraturan pemerintah pengganti UU Nomor 1 Tahun 2014 tentang pemilihan Gubernur, Bupati, dan Walikota, yaitu pasal 188 jounto pasal 71 ayat 1 . SF dinyatakan aktif mengkampanyekan pasangan calon Wali/Wakil Wali Kota Bima 2018.

Dari uraian di atas menunjukkan bahwa pelanggaran terhadap Dampak Pelanggaran ASN Atas SE MENPANRB N0. B/2355/M. Panrb/07/2015 dari sisi pendekatan kasus akan memberikan akibat pidana yang merugikan ASN tersebut, dengan ketegasan dari para pihak penyelenggara pemilu yang tergabung dalam Gakkumdu diharapkan netralitas ASN akan terus terjaga dan tidak akan berani lagi untuk melakukan perbuatan yang melanggar kode etik yang telah diatur dalam UU N0 5 Tahun 2014 tentang ASN tersebut, karena memiliki konsekwensi baik administratif dan juga unsur hukum pidana yang ancamannya 36 bulan. Tentu saja hal ini akan menjadi pelajaran yang berharga bagi ASN lainnya.

\section{KESIMPULAN}

Dari uraian di atas dapat disimpulkan bahwa Dampak Pelanggaran Tehadap Surat Edaran MenPANRB tersebut memiliki 2 konsekwensi baik secara administratif Kepegawaian maupun secara hukum pidana, bergantung pada jenis pelanggaran yang dilakukan dan penggunaan peraturan yang diterapkan, yaitu: Pelanggaran disiplin pegawai dengan kategori berat berakibat pada pemberhentian dari jabatan negeri atau pemberhentian dari jabatan kemudian jika terbukti melakukan pelanggaran sesuai peraturan Pemilu dapat berakibat pada ancaman pidana dengan kurungan 36 bulan.

\section{DAFTAR PUSTAKA}

\section{Buku}

Muchsan. Hukum Kepegawaian. Jakarta: Bina Aksara. 1982.
Satya Adi Permana, Lalu Sabardi, Djumardin. Tanggung Jawab Notaris Atas Akta Salinan Yang Dibuat Tanpa Minuta Akta. Jurnal Hukum Jatiswara, [S.1.], v. 32, n. 2, nov. 2017. ISSN 2579-3071. Available at: <http:// jatiswara.unram.ac.id/index.php/js/ article/view/122>. Date accessed: 17 feb. 2019.

A. Patria. Intervensi Politik dan Netralitas Aparatur Sipil Negara dalam Pemilihan Umum Kepala Daerah Provinsi Lampung Tahun 2014. Bandar Lampung: Fakultas Ilmu Sosial dan Ilmu Politik Universitas Lampung. 2015.

M. N. Watunglawar. Perwujudan Asas Netralitas Birokrasi dalam UndangUndang Nomor 5 Tahun 2014 Tentang Aparatur Sipil Negara. Jember: Program Pacasarjana Universitas Jember. 2015.

M. H. Yamin. Netralitas Pegawai Negeri Sipil dalam Pemilihan Umum Kepala Daerah di Kabupaten Takalar. Makasar: Bagian Hukum Tata Negara Fakultas Hukum UU No. 5 Tahun 2014 tentan ASN. 2015.

\section{Media Online}

KBBI Online, 2010

Lombok Post.net 26 Februari 2018

\section{Peraturan Perundang-undangan}

UU No. 5 Tahun 2014 tentang ASN

UU No. 10 Tahun 2016 tentang perubahan kedua atas UU Nomor 1 Tahun 2015 tentang penetapan peraturan pemerintah pengganti UU Nomor 1 Tahun 2014 tentang pemilihan Gubernur 